\title{
TINGKAT KECUKUPAN ENERGI PROTEIN PADA IBU HAMIL TRIMESTER PERTAMA DAN KEJADIAN KEKURANGAN ENERGI KRONIS
}

\author{
Energy and Protein Adequacy Level in First Trimester of Pregnancy and the Occurance of \\ Cronic Energy Deficiency
}

\author{
Anisatun Azizah', Merryana Adriani² \\ ${ }^{1}$ Program Studi S1 Kesehatan Masyarakat, Fakultas Kesehatan Masyarakat, Universitas Airlangga, Surabaya \\ ${ }^{2}$ Departemen Gizi Kesehatan, Fakultas Kesehatan Masyarakat, Universitas Airlangga, Surabaya \\ Email: anisatunazizah2@gmail.com
}

\begin{abstract}
ABSTRAK
Kasus Kekurangan Energi Kronis (KEK) banyak terjadi di Indonesia terutama disebabkan oleh ketidakseimbangan asupan gizi sehingga dapat mengakibatkan pertumbuhan tubuh baik fisik maupun mental yang tidak sempurna. Usia kehamilan yang paling penting adalah usia trimester pertama karena pada usia tersebut terbentuk berbagai organ vital janin. Tujuan penelitian ini adalah untuk menganalisis hubungan antara tingkat kecukupan energi protein dengan kejadian KEK pada ibu hamil trimester pertama. Penelitian ini adalah penelitian observasional analitik dengan menggunakan desain cross sectional. Besar sampel sebanyak 22 orang ibu hamil trimester pertama yang dipilih dengan cara simple random sampling. Analisis data menggunakan uji chi square dan fisher exact $(\alpha=0,05)$. Hasil penelitian menunjukkan bahwa terdapat 50\% ibu hamil mengalami KEK dan 50\% tidak mengalami KEK. Berdasarkan tabulasi silang, ibu hamil yang memiliki tingkat kecukupan protein yang kurang (53\%) memiliki prevalensi KEK yang tidak berbeda dengan kecukupan protein yang baik (47\%). Uji hubungan menunjukkan tidak terdapat hubungan antara tingkat kecukupan karbohidrat $(\mathrm{p}=1,000)$, protein $(\mathrm{p}=1,000)$, dan lemak $(\mathrm{p}=0,635)$ dengan KEK ibu hamil $(\mathrm{p}>0,05)$.
\end{abstract}

Kata-kata kunci: Ibu hamil trimester pertama, KEK, tingkat kecukupan gizi

\begin{abstract}
Chronic Energy Deficiency (CED) cases are still occur in Indonesia, mainly due the imbalance of nutrients intake and it can lead to the growth retardation, either physical or mental. The most important period of the gestational age is at the first trimester because the formation of various vital organs of the fetus occurs. The purpose of this research was to analyze the relationship between energy and protein adequacy level with the occurance of CED in the first trimester of pregnant women. This research was an observational analytic study with cross sectional design. The number of sample taken was 22 people which randomly selected. The data was analyzed using chi square and fisher exact test $(\alpha=0,05)$. The results showed that there were 50\% of pregnant women having Chronic Energy Deficiency and 50\% did not have Chronic Energy Deficiency. Based on cross-tabulation, pregnant women who have low protein adequacy level have a similar CED prevalence with good protein adequacy level. There was no relationship between carbohydrate $(p=1,000)$, protein $(p=1,000)$, and fat $(p=0,635)$ adequacy level with CED in pregnant women $(p>0,05)$.
\end{abstract}

Keywords: first trimester of pregnant women, CED, nutrient adequacy level

\section{PENDAHULUAN}

Indonesia merupakan negara yang kaya akan Sumber Daya Alam namun banyak terjadi kasus Kekurangan Energi Kronis (KEK). Hal tersebut disebabkan oleh ketidakseimbangan asupan zat gizi sehingga dapat mengakibatkan ketidaksempurnan pertumbuhan tubuh baik fisik maupun mental (Chinue, 2009).
Salah satu masalah gizi yang dihadapi di Indonesia adalah masalah gizi pada masa kehamilan. Gizi pada masa kehamilan adalah salah satu faktor penting yang mempengaruhi perkembangan embrio dan janin serta status kesehatan ibu hamil. Kehamilan merupakan tahapan yang berkesinambungan, sehingga defisiensi pada suatu periode akan memberikan 
dampak secara berbeda pada outcome kehamilan. Periode perikonsepsional terdiri dari prekonsepsi, konsepsi, implantasi, plasentasi, serta masa embryogenesis. Kualitas bayi yang dilahirkan sangat tergantung pada keadaan gizi ibu sebelum dan selama kehamilan (Cetin, et al., 2009).

Menurut hasil Riskesdas tahun 2007, provinsi Jawa Timur merupakan salah satu dari 10 provinsi di Indonesia dengan prevalensi KEK penduduk wanita usia subur di atas pevalensi nasional (13,6\%). Sementara hasil Riskesdas tahun 2013 menunjukkan bahwa prevalensi penduduk wanita usia subur (usia 15-49 tahun) sedang hamil dan mengalami risiko KEK di Jawa Timur sebesar $29,8 \%$, sedangkan di tingkat nasional prevalensi penduduk WUS yang sedang hamil dan mengalami risiko KEK sebesar 24,2\%. Hal ini menunjukkan bahwa penduduk WUS yang sedang hamil dan KEK di Jawa Timur masih lebih tinggi daripada di tingkat nasional.

Prevalensi ibu hamil Kekurangan Energi Kronis di Kediri tahun 2013 dan 2014 sebesar 6,6\% dan $6,7 \%$. Hal ini menunjukkan bahwa pada tahun 2014, angka KEK ibu hamil di Kediri mengalami kenaikan $0,1 \%$ dari tahun sebelumnya. Prevalensi ibu hamil KEK di Puskesmas Badas tahun 2013 dan 2014 sebesar 7,8\% dan 6,1\%. Adapun angka BBLR di Kediri tahun 2013 dan 2014 sebesar $2,71 \%$ dan 2,46\%. Angka BBLR di Kediri pada tahun 2014 mengalami penurunan sebesar 0,15\% (Dinas Kesehatan Kabupaten Kediri, 2013 dan 2014).

Wanita yang menderita malnutrisi sebelum hamil atau selama minggu pertama kehamilan cenderung melahirkan bayi yang menderita kerusakan otak dan sumsum tulang karena sistem saraf pusat sangat peka pada 2-5 minggu pertama. Apabila hal tersebut diderita ibu hingga sepanjang minggu terakhir kehamilan, maka ibu akan melahirkan bayi dengan berat badan lahir rendah $(<2500$ gram) (Arisman, 2009).

\section{METODE PENELITIAN}

Penelitian observasional dengan rancangan cross sectional ini dilakukan di wilayah kerja Puskesmas Badas, Kecamatan Badas, Kabupaten Kediri pada bulan Juli 2015. Populasi trimester pertama sebanyak 50 orang ibu hamil di Puskesmas Badas Kabupaten Kediri tahun 2015. Adapun kriteria inklusi sampel dalam penelitian ini adalah usia kandungan ibu hamil memasuki trimester pertama, tidak menderita penyakit baik kronis maupun akut, meliputi TBC, kelainan jantung, dan DM. Besar sampel dihitung menggunakan rumus korelasi antar dua variabel dengan harga koefisien korelasi (r) sebesar $0,57, \alpha=5 \%$, dan power $=80 \%$. Berdasarkan rumus tersebut diperoleh sampel sebesar 22 ibu hamil trimester pertama.

Pengambilan sampel dilakukan dengan teknik simple random sampling yakni setiap anggota atau unit dari populasi mempunyai kesempatan yang sama untuk dipilih sebagai sampel. Penelitian ini terdiri dari dua variabel, variabel bebas yaitu tingkat kecukupan gizi (karbohidrat, protein, dan lemak) dan variabel tergantung yaitu status gizi ibu hamil (kekurangan energi kronis).

Data yang dikumpulkan dalam penelitian ini terdiri atas data primer yang diperoleh secara langsung melaui wawancara dengan menggunakan kuesioner, form Food Recall $2 \times 24$ jam, form Food Frequency, data catatan gizi melalui KMS dan pengukuran lingkar lengan atas (LILA) menggunakan pita LILA. Data sekunder meliputi jumlah ibu hamil dari seluruh Bidan Desa di wilayah kerja Puskesmas Badas. Data yang telah dikumpulkan kemudian dianalisis menggunakan uji Chi Square dan Fisher Exact dengan $\alpha=0,05$ Penelitian ini telah mendapatkan persetujuan dari Komisi Etik nomor 374-KEPK Fakultas Kesehatan Masyarakat Universitas Airlangga.

\section{HASIL DAN PEMBAHASAN}

Penyebab Kekurangan Energi Kronis (KEK) akibat adanya ketidakseimbangan antara asupan dalam pemenuhan gizi dan pengeluaran energi (Erma, dkk., 2013). Karakteristik responden dalam penelitian ini meliputi status Kekurangan Energi Kronis (KEK) dan tingkat kecukupan gizi ibu hamil (karbohidrat, protein, dan lemak). Berikut disajikan karakteristik ibu hamil trimester pertama.

Berdasarkan Tabel 1, diperoleh bahwa sebagian responden $(94,5 \%)$ mengalami KEK 
Tabel 1. Distribusi Frekuensi Karakteristik Ibu Hamil Trimester I

\begin{tabular}{lrc}
\hline \multicolumn{1}{c}{ Karakteristik } & n & $\begin{array}{c}\text { Persentase } \\
(\%)\end{array}$ \\
\hline KEK & & \\
Ya (LILA $<23,5 \mathrm{~cm})$ & 11 & 50,0 \\
$\quad$ Tidak (LILA $\geq 23,5 \mathrm{~cm})$ & 11 & 50,0 \\
Tingkat Kecukupan Karbohidrat & & \\
$\quad$ Sedang-Baik & 21 & 95,5 \\
$\quad$ Kurang-Defisit & 1 & 4,5 \\
Tingkat Kecukupan Protein & & \\
$\quad$ Sedang-Baik & 4 & 18,2 \\
$\quad$ Kurang-Defisit & 18 & 81,8 \\
Tingkat Kecukupan Lemak & & \\
$\quad$ Sedang-Baik & 16 & 72,7 \\
$\quad$ Kurang-Defisit & 6 & 27,3 \\
Jumlah & 22 & 100,0 \\
\hline
\end{tabular}

(50\%) dan sebagian tidak mengalami KEK (50\%). Adapun tingkat kecukupan karbohidrat, mayoritas responden memiliki konsumsi sedangbaik $(80 \%-\geq 100 \% \mathrm{AKG})$, sedangkan tingkat kecukupan protein sebagian besar responden $(81,8 \%)$ mengalami kurang-defisit $(<70-79 \%$ AKG) dan tingkat kecukupan lemak sebagian besar responden $(72,7 \%)$ adalah sedang-baik $(80 \%-\geq 100 \%$ AKG).

\section{Kekurangan Energi Kronis (KEK)}

Faktor yang berpengaruh terhadap kejadian kekurangan energi kronis adalah pola makan yang kurang beragam dan porsi yang kurang. Dampak dari ketidakseimbangan asupan gizi ibu hamil dapat menimbulkan gangguan selama kehamilan, baik terhadap ibu maupun janin yang dikandungnya. Apabila kondisi ini berlangsung dalam waktu yang lama maka akan terjadi ketidakseimbangan asupan untuk pemenuhan kebutuhan dan pengeluaran energi sehingga menyebakan ibu hamil mengalami Kekurangan Energi Kronis (Yuliastuti, 2013).

Kehamilan menyebabkan meningkatnya metabolisme energi, seperti diketahui bahwa sumber energi makanan dapat mempengaruhi pertumbuhan janin. Faktor gizi telah lama dianggap sebagai penentu dari kesehatan ibu dan janin (Moore, et al., 2004). Status gizi ibu berperan dalam perkembangan bayinya (Meltzer, et al., 2011). Kekurangan zat gizi tertentu yang diperlukan saat hamil dapat menyebabkan janin tumbuh tidak sempurna (Raiten, et al., 2007).
Menurut Ratzan, et al. (2000) kekurangan gizi merupakan spektrum gizi yang berhubungan dengan ganggua $\mathrm{n}$, kekurangan, dan kondisi retardasi pertumbuhan intrauterin, malnutrisi energi-protein dan kekurangan zat yodium, kekurangan vitamin A, dan defisiensi besi anemia.

Malnutrisi menimbulkan berbagai ancaman terhadap wanita, di antaranya melemahkan kemampuan wanita untuk melahirkan, lebih mudah terkena infeksi, dan kemampuan untuk bisa pulih dari penyakit lebih sedikit. Selain itu, malnutrisi pada wanita juga bisa mengurangi kemampuan produktivitas mereka, sehingga dalam hal pekerjaan bisa mengurangi pendapatan mereka, dan mengurangi kemampuan mereka untuk merawat keluarga. Hal tersebut mengakibatkan kerugian ekonomi keluarga, masyarakat dan negara (Pelletier and Frongillo, 2003, dalam Kulasekaran, 2012). Dampak gizi buruk ibu sebelum dan selama hamil dapat menyebabkan pertumbuhan janin terhambat (PJT), berat badan bayi lahir rendah (BBLR), gangguan pertumbuhan dan perkembangan berbagai organ vital bayi serta meningkatnya risiko kesakitan dan kematian bayi (Yongki, dkk., 2009)

\section{TINGKAT KECUKUPAN IBU HAMIL}

\section{Tingkat Kecukupan Karbohidrat}

Karbohidrat merupakan sumber tenaga untuk tumbuh kembang janin dan proses perubahan biologis yang terjadi dalam tubuh meliputi pembentukan sel baru, pemberian makanan bayi melalui plasenta, pembentukan enzim dan hormon penunjang pertumbuhan janin (Kristiyanasari, 2010). Hasil penelitian menunjukkan bahwa antara tingkat kecukupan karbohidrat ibu hamil trimester pertama sedang-baik yang tidak mengalami KEK dengan tingkat kecukupan karbohidrat ibu hamil trimester pertama sedang-baik yang mengalami KEK, mempunyai persentase yang sama yaitu $50 \%$. Adapun tingkat kecukupan karbohidrat ibu hamil trimester pertama kurang-defisit $(<70 \%-79 \%)$ yang tidak mengalami KEK dengan tingkat kecukupan karbohidrat ibu hamil trimester pertama kurang-defisit yang mengalami KEK juga mempunyai persentase yang sama yaitu $50 \%$. 
Ibu hamil trimester pertama, mayoritas memiliki tingkat kecukupan karbohidrat sedang-baik $(80 \%-\geq 100 \%)$ yakni sebesar 20 orang dari 22 responden.

Hasil analisis hubungan menggunakan uji Fisher Exact pada penelitian ini menunjukkan bahwa tidak ada hubungan yang bermakna dengan nilai $p=1,000(p>0,05)$. Hasil tersebut menunjukkan bahwa antara ibu hamil tingkat kecukupan karbohidrat sedang-baik dengan tingkat kecukupan karbohidrat kurang-defisit, memiliki persentase yang sama dan sama-sama berisiko untuk mengalami KEK. Konsumsi karbohidrat yang berada di atas Angka Kecukupan Gizi (AKG) tersebut disebabkan pola kebiasaan makan masyarakat yang mayoritas sama yakni lebih banyak mengkonsumsi makanan yang bersumber dari karbohidrat.

Penelitian ini sejalan dengan penelitian Djamilah (2008) dan Mulyaningrum (2009) yang menyatakan bahwa tidak terdapat hubungan yang bermakna antara tingkat kecukupan energi ibu hamil trimester pertama dengan KEK. Menurut Hardinsyah (2007), konsumsi pangan sebelum dan selama kehamilan berpengaruh pada status gizi ibu hamil. Ibu hamil yang cukup konsumsi pangan dan gizinya akan jarang mengalami masalah yang berarti selama kehamilan. Status gizi sebelum kehamilan merupakan salah satu faktor yang mempengaruhi gizi.

\section{Tingkat Kecukupan Protein}

Tingkat kecukupan protein ibu hamil trimester pertama sedang-baik $(80 \%-\geq 100 \%)$, mayoritas tidak mengalami KEK, sedangkan tingkat kecukupan protein ibu hamil trimester pertama kurang-defisit $(<70 \%-79 \%$ AKG), mayoritas (53\%) mengalami Kekurangan Energi Kronis (KEK) (77\%). Ibu hamil trimester pertama mayoritas mengalami tingkat kecukupan protein adalah kurang-defisit ( $<70-79 \%$ AKG). Hasil uji Fisher Exact diperoleh nilai $p=1,000(p>0,05)$ yang menunjukkan tidak adanya hubungan antara tingkat kecukupan protein ibu hamil trimester pertama dengan kejadian KEK.

Hasil analisis pola konsumsi pangan sumber protein menunjukkan bahwa $31,8 \%$ ibu hamil setiap hari mengonsumsi protein nabati berupa tahu dan tempe, sedangkan $100 \%$ dan $95,5 \%$ ibu hamil tidak pernah mengonsumsi jeroan dan daging sapi/udang baik kepiting. Daging/udang/ kepiting merupakan sumber protein yang bagus dan berfungsi untuk menjaga kesehatan, pertumbuhan plasenta, cairan amnion, pembentuk jaringan baru pada janin, pertumbuhan berbagai organ janin, perkembangan organ kandungan ibu hamil, dan penambahan volume darah. Dampak kekurangan asupan protein adalah gangguan pertumbuhan pada janin, seperti retardasi intrauterine, cacat bawaan, BBLR, dan keguguran (Kristiyanasari, 2010).

Penelitian ini sejalan dengan penelitian Usmelinda (2015) dan Asrul (2013) bahwa tidak terdapat hubungan yang bermakna antara tingkat kecukupan protein dengan kejadian KEK pada ibu hamil, namun penelitian ini tidak sejalan dengan penelitian Efrinita (2010) yang menyatakan bahwa terdapat hubungan yang bermakna antara konsumsi protein dengan kejadian KEK.

Kebiasaan mengonsumsi lebih banyak protein nabati dibandingkan dengan protein hewani menyebabkan absorbsi zat besi kurang optimal. Hal ini dikarenakan protein hewani mengandung heme yang diperlukan oleh tubuh (Krisnawati, 2010).

\section{Tingkat Kecukupan Lemak}

Lemak berfungsi sebagai sumber kalori untuk persiapan menjelang persalinan dan untuk memetabolisme vitamin A, D, E, dan K. Sumber makanan yang dapat menghasilkan lemak yaitu minyak, margarin, dan mentega (Kristiyanasari, 2010).

Tingkat kecukupan lemak ibu hamil trimester pertama sedang-baik $(80 \%-\geq 100 \%$ AKG), mayoritas tidak mengalami KEK sebesar $56,25 \%$, sedangkan tingkat kecukupan lemak ibu hamil trimester pertama kurang-defisit $(<70 \%-79 \%$ AKG), mayoritas mengalami Kekurangan Energi Kronis (KEK) sebesar 66,7\%. Ibu hamil trimester pertama mayoritas yang mengalami tingkat kecukupan lemak adalah sedang-baik $(80 \%-\geq 100 \%$ AKG) sebesar 16 orang dari 22 responden (73\%). Hasil uji hubungan menggunakan Fisher Exact diperoleh nilai $p=0,635(p>0,05)$ yang menunjukkan tidak adanya hubungan antara tingkat kecukupan lemak ibu hamil trimester 
Tabel 2. Tingkat Kecukupan Ibu Hamil Trimester I pada Kelompok Kekurangan Energi Kronis (KEK) dan Tidak Kekurangan Energi Kronis (Non-KEK)

\begin{tabular}{|c|c|c|c|c|c|c|}
\hline \multirow{2}{*}{ Tingkat Kecukupan } & \multicolumn{2}{|c|}{$\begin{array}{c}\text { KEK } \\
(n=11)\end{array}$} & \multicolumn{2}{|c|}{$\begin{array}{c}\text { Non KEK } \\
(\mathrm{n}=11)\end{array}$} & \multirow{2}{*}{$\begin{array}{c}\text { Total } \\
(n=22)\end{array}$} & \multirow{2}{*}{ p-value } \\
\hline & $\mathbf{n}$ & $\%$ & $\mathbf{n}$ & $\%$ & & \\
\hline \multicolumn{7}{|l|}{ Karbohidrat } \\
\hline Sedang-Baik & 10 & 50,00 & 10 & 50,00 & 20 & \multirow{2}{*}{1,000} \\
\hline Kurang-Defisit & 1 & 50,00 & 1 & 50,00 & 2 & \\
\hline \multicolumn{7}{|l|}{ Protein } \\
\hline Sedang-Baik & 2 & 40,00 & 3 & 60,00 & 5 & \multirow{2}{*}{1,000} \\
\hline Kurang-Defisit & 9 & 53,00 & 8 & 47,00 & 17 & \\
\hline \multicolumn{7}{|l|}{ Lemak } \\
\hline Sedang-Baik & 7 & 43,75 & 9 & 56,25 & 16 & \multirow[t]{2}{*}{0,635} \\
\hline Kurang-Defisit & 4 & 66,67 & 2 & 33,33 & 6 & \\
\hline
\end{tabular}

pertama dengan kejadian KEK. Asupan lemak yang berada di atas AKG tersebut dapat disebabkan karena faktor kebiasaan makan masyarakat yang sama dan lebih banyak mengonsumsi makanan yang bersumber dari lemak. Penelitian ini sejalan dengan penelitian Djamilah (2008) dan Usmelinda (2015) bahwa tidak terdapat hubungan yang bermakna antara tingkat kecukupan lemak dengan kejadian KEK pada ibu hamil.

Pada penelitian ini, tingkat kecukupan protein, karbohidrat, dan lemak tidak berhubungan dengan kejadian KEK. Hal ini dapat dikarenakan pengumpulan data konsumsi pangan menggunakan food recall $2 \times 24$ jam. Metode ini menggambarkan konsumsi makan responden dalam kisaran waktu yang singkat. Sementara kekurangan energi kronis merupakan masalah gizi yang terjadi dalam kurun waktu yang lama.

\section{KESIMPULAN DAN SARAN}

Tingkat kecukupan (karbohidrat, lemak, dan protein) ibu hamil trimester pertama tidak memiliki hubungan yang signifikan terhadap kejadian Kekurangan Energi Kronis (KEK). Peningkatan pengetahuan untuk remaja putri, calon pengantin, dan ibu hamil mengenai perlunya mengonsumsi makanan bergizi dan mengandung protein (baik hewani maupun nabati) dalam jumlah yang cukup dan beragam tetap perlu dilakukan agar terwujud status gizi ibu hamil yang optimal.

\section{DAFTAR PUSTAKA}

Arisman. (2009). Gizi dalam daur kehidupan edisi 2. Jakarta: Penerbit Buku Kedokteran EGC.

Asrul, I.A., Abdul, R., \& Devinta, V. (2013). Hubungan asupan energi dengan status IMT dan LILA ibu prakonsepsional di Kecamatan Ujung Tanah dan Biringkanaya Kota Makassar. Diakses dari http://repository.unhas.ac.id/ handle/123456789/6259.

Cetin, I., Berti, C., \& Calabrese, S. (2009). Role of micronutrients in the pereinceptional period. Human Reproduction Update, 16 (1), 80-95. https://doi.org/10.1093/humupd/dmp025

Chinue, C. (2009). Kekurangan energi kronik (KEK). Diakses dari http://chinue.wordpress. com/2009/03/14/makalah-kek/.

Dinas Kesehatan Kabupaten Kediri. (2014). Tentang laporan tahunan Kabupaten Kediri Provinsi Jawa Timur (2013 dan 2014). Badan Penelitian Pengembangan dan Kesehatan

Djamilah, A. (2008). Faktor-faktor yang berhubungan dengan kurang energi kronis pada ibu hamil di wilayah Puskesmas Jembatan Serong Kecamatan Pancoran Mas Depok Jawa Barat (Skripsi yang tidak dipublikasikan). Universitas Indonesia, Depok.

Efrinita, N.A. (2010). Hubungan antara asupan protein dengan kekurangan energi kronik (KEK) pada ibu hamil di Kecamatan Jebres Surakarta. (Skripsi yang tidak dipublikasikan). Universitas Sebelas Maret, Surakarta.

Erma, S.A., Jafar, N., \& Indriasari, R. (2013). Hubungan pola makan dan status sosial 
ekonomi dengan kejadian KEK pada ibu hamil di Kabupaten Gowa tahun 2013. Diakses dari http://repository.unhas.ac.id/ handle/123456789/5508

Hardinsyah. (2007). Review faktor determinan keragaman konsumsi pangan. Jurnal Gizi dan Pangan, 2(2), 55 - 745. Diakses dari jai.ipb.ac.id/index.php/jgizipangan/article/ viewFile/4424/2976

Kemenkes RI. (2013). Riskesdas tahun 2013 tentang Laporan Provinsi Jawa Timur (2013). Badan Penelitian dan Pengembangan Kesehatan.

Krisnawati, N. (2010). Hubungan antara tingkat kecukupan pada ibu hamil dengan kejadian kekurangan energi kronis (KEK) di Puskesmas Wonoayu Kabupaten Sidoarjo. (Skripsi yang tidak dipublikasikan). Universitas Airlangga, Surabaya.

Kristiyanasari, W. (2010). Gizi ibu hamil. Yogyakarta: Nuha Medika.

Kulasekaran, R.A. (2012). Influence of mothers' chronic energy deficiency on the nutritional status of preschool children in empowered action group states in India. International Journal of Nutrition, Pharmacology, Neurogical Disease, 2 (1), 198-209. Diakses dari http:// www.ijnpnd.com/article.asp?issn=2231-0738; year $=2012 ;$ volume $=2 ;$ issue $=3 ;$ spage $=198$; epa ge $=209$; aulast $=$ Kulasekaran; type $=0$

Mulyaningrum, S. (2009). Faktor-faktor yang berhubungan dengan risiko kurang energi kronis (KEK) pada ibu hamil di Provinsi DKI Jakarta (Skripsi yang tidak dipublikasikan). Universitas Indonesia, Depok.

Meltzer, H.M., Brantsæter, A.L., Nilsen, R.M., Magnus, P., Alexander, J., \& Haugen, M. (2011). Effect of dietery factors in pregnancy on risk of pregnancy complication. Result from the Norwegian mother and child cohorts study. Am J Clin Nutr, 94(6), 1970S-1974S. doi: 10.3945/ ajen.110.001248

Moore, V.M., Davies, M.J., Willson, K.J., Worsley, A., \& Robinson, J.S. (2004). Dietery composition of pregnant woman is related to size of the baby at birth. Journal Of Nutrition, 134(7), 18201826.

Pelletier, D.L., \& Frongillo, E.A. (2003). Changes in child survival are strongly associated with changes in malnutrition in developing countries. J Nutr, 133(1), 107-119.

Ratzan, S.C., Filerman, G.L., \& Lesar, J.W. (2000). Attaining global health: Challenges and opportunities. Population Bulletin of the Popoullation Reference Bureau, 55(1), 1-48.

Raiten, D.J., Kalhan, S.C., \& Hay, W.W.Jr. (2007). Maternal nutrition and optimal infant feeding practices: Executive summary. AM Journal Clinc Nutr, 85(2), 577S-583S.

Usmelinda, S.W. (2015). Analisa pola makan, ibu hamil dengan kekurangan energi kronis di Kecamatan Bobotsari Kabupaten Purbalingga (Skripsi yang tidak dipublikasikan). Universitas Negeri Yogyakarta, Yogyakarta. Diakses dari http://eprints.uny.ac.id/id/21590

Yongki, Hardinsyah, Gulardi, \& Marhamah. (2009). Status gizi awal kehamilan dan pertambahan berat badan ibu hamil kaitannya dengan BBLR. Jurnal Gizi dan Pangan, 4(1), 8-12.

Yuliastuti, E. (2013). Faktor-faktor yang berhubungan dengan kekurangan energi kronis pada ibu hamil di Wilayah Kerja Puskesmas Sungai Bilu Banjarmasin. Jurnal An Nadaa, 1(2), 72-76. 